\title{
Data sources regarding the nonmedical use of pharmaceutical opioids in the United States
}

Teresa Schmidt ${ }^{1}$, Amanuel Zimam ${ }^{1}$, Alexandra Nielsen ${ }^{1}$, Wayne Wakeland ${ }^{1}$

1 Systems Science Graduate Program Portland State University

\section{Abstract}

Objective: Recent increases in the nonmedical use of pharmaceutical opioids and the adverse outcomes associated with them have stimulated a large amount of research and data collection on this public health problem. Systematic organization of the available data sources is needed to facilitate ongoing research, analysis, and evaluation. This work offers a systematic categorization of data sources regarding the nonmedical use of pharmaceutical opioids in the United States.

Methods: A list of keywords regarding the nonmedical use of pharmaceutical opioids was used to conduct systematic searches in PubMed ${ }^{\oplus}$. Filtration of search results generated 92 peer-reviewed academic articles, published between January 1995 and April 2012, as well as a number of primary data sources. Lists of topics were developed independently by two researchers which were later compared and consolidated. All sources were then categorized according to their relevance to each of these topics and according to their capacity for geographical and longitudinal trend analysis.

Results: Tables cataloging data sources can be used to identify data relevant to specific topics in diversion, nonmedical use, and adverse outcomes associated with pharmaceutical opioids, and they illustrate global trends in data coverage, identifying several topics that have minimal data. A network diagram illustrates global trends in data coverage, showing variation among sources in the number of topics they cover, as well as variation among topics in the number of sources that cover them.

Conclusions: The categorization of data sources is hoped to facilitate ongoing research, analysis, and evaluation of this public health problem by serving as a guide for researchers, policy makers, and others who seek data regarding the nonmedical use of pharmaceutical opioids in the United States.

\section{Keywords}

Pharmaceutical opioids, Data sources; Nonmedical use 


\section{Introduction}

A dramatic rise in the nonmedical use of pharmaceutical opioids presents the United States with a substantial public health problem [1]. The 2011 National Survey of Drug Use and Health (NSDUH) estimates that 2.3 percent of the US population used pain relievers nonmedically during the past month, and that at least 1.9 million individuals have initiated nonmedical use each year since 2002 [2]. Such medications are now among the most popular drugs for nonmedical use, second only to marijuana [3], and are associated with a variety of adverse outcomes. The number of overdose deaths involving opioids increased threefold between 1999 and 2006, and fivefold among youth aged 15 to 24 [4]. Use disorders involving pain reliever abuse or dependence were estimated to afflict 1.4 million individuals in 2011, one third of whom were young adults between the ages of 18 and 25 [2]. Many of the pharmaceutical opioids that are used nonmedically are diverted in some way from their legally intended purpose: over half of nonmedical users report acquiring their most recent supply of pain relievers from a friend or relative, and among them, over three quarters report that their friend or relative had acquired the pain relievers from a doctor [2-5].

Considerable research has been conducted on the public health problems surrounding nonmedical use of pharmaceutical opioids. Large scale primary data collection methods, such as the NSDUH, the National Poison Data System (NPDS), and the Drug Abuse Warning Network (DAWN) have enabled a large number of analyses on the prevalence [6-7], characteristics [8-9], and adverse outcomes [10-11] associated with nonmedical opioid use. Smaller, independent studies have measured prevalence among a number of prominent subpopulations, such as physicians [12], anesthesiologists [13], and student pharmacists [14], and have been instrumental in identifying additional factors that are relevant to this public health problem. These factors include polydrug use [15], mental health problems [16], social support [17], and routes of diversion [18].

Because of the large number of data sources available for studying nonmedical opioid use and the wide range of relevant factors, systematic organization of data sources is needed to facilitate ongoing research, analysis, and evaluation of this public health problem. Initial efforts organize data sources according to topic [19] and geographical scale [20]; however a systematic approach has not yet been employed in the search and categorization of existing data sources. This work provides a systematic approach to the collection and categorization of data sources along a set of prominent topics in the field, providing a guide for researchers, policy-makers, and others who seek data on various aspects of the nonmedical use of pharmaceutical opioids in the United States.

\section{Methods}

This work was conducted to advance a larger research project which uses System Dynamics modeling to investigate the nonmedical use of pharmaceutical opioids in the United States. System Dynamics is a computer simulation methodology that describes a system in terms of stocks and flows which are governed by differential equations [21-22]. This methodology is capable of incorporating a large range of available data into a systems-level model that represents the global dynamics of the system of interest [23].

\section{Keyword searches}

To provide empirical support for the specification of a System Dynamics model, data sources were systematically sought out for their relevance to the diversion, nonmedical use, and adverse outcomes associated with pharmaceutical opioids in the United States. This investigation began with a list of keywords which were identified from the project's previously established collection of electronic resources, 
including journal articles, government documents, and reports regarding the public health problem of nonmedical opioid use. The list was compiled by scanning through documents for words listed in a "keywords" field, and was then simplified by omitting keywords of non-opioid drugs and substances, specific drug formulation names (e.g., Fentanyl, OxyContin), words pertaining specifically to medical treatment, and other words that were not directly related to the phenomena of interest (e.g., screening instrument, prevention, mental health, triplicates). The final list of keywords was grouped into diversion, nonmedical use, and adverse outcome categories, and used in three PubMed searches for peer-reviewed academic articles published between January 1, 1995, and May 1, 2012. The specific searches, submitted to PubMed ${ }^{\bullet}$ in May of 2012, are included in Table I.
1 (Opioid OR Opioids) AND (Misuse OR Noncompliance OR "Non-compliance" OR Diversion) AND ("1995/01/01" [Date - Publication] : "2012/05/01" [Date - Publication])

2 (Opioid OR Opioids) AND (Deaths OR “Drug-related harm" OR "Fatal Outcome" OR Mortality OR Overdose OR Poisoning) AND ("1995/01/01" [Date Publication] : “2012/05/01" [Date - Publication])

3 (Opioid OR Opioids) AND (Abuse OR "Aberrant drug-related behaviors" OR Addiction OR "Abuse Liability" OR "Problem Drug Use" OR "Substance Use Disorders" OR "Substance-Related Disorders" OR "Substance related disorders" OR "Nonmedical Use" OR "Non-medical Use" OR "Non medical Use") AND ("1995/01/01"[Date - Publication] : "2012/05/01" [Date - Publication])

Table I. Opioid Searches Submitted to PubMed $^{\circledR}$ in May 2012

\section{Source filtration}

Literature searches conducted in PubMed ${ }^{\bullet}$ returned a large number of hits regarding diversion $(1,506)$, nonmedical use $(15,512)$, and adverse outcomes $(4,508)$. These studies were filtered by a team of three graduate students with the following search criteria: all journal articles were required to be peer reviewed, to be available in the English language, to contain quantitative data on human subjects, to have a minimum sample size of 30 participants, and to have direct relevance to the US population. Studies on medical treatment with pharmaceutical opioids were excluded, including treatment for opioid or opiate dependence. Articles which analyzed secondary data were also excluded, but the primary data sources used were noted for inclusion in the categorization process described below.

A filtered collection of 92 articles meeting the search criteria were evaluated qualitatively by two graduate students, who independently created lists of the most prominent topics. The two lists were compared, and differences between them were resolved through discussion, resulting in a final list of 20 topics. These topics were grouped for their relevance to diversion, nonmedical use, and adverse outcomes, as they appear in Tables II through IV. At a later time point, two design features were identified as salient, as several articles reported analyses of longitudinal and/or geographic trends. These attributes are included in the Appendix.

\section{Categorization}

A list of sources was created, including the 92 filtered articles and 42 additional primary sources that had been noted during the filtration process. Each source was categorized by the geographical scale at which it was collected, and for its relevance to any of the 20 topics and 2 design attributes. Closer examination of articles during this phase resulted in several more instances of exclusion, for reasons of confounding (e.g., opioids with heroin; nonmedical with medical use), absence of original data (e.g., review articles, secondary analyses), or research on excluded topics (e.g., search algorithms for postmarketing surveillance, healthcare costs among nonmedical users). Several primary sources were also excluded during the categorization phase, for reasons of duplication (e.g., Veterans Affairs and Veterans Health Administration), and measurement of excluded topics (e.g., adverse events, which imply medical use). This resulted in a final list of 35 original research articles as well as 22 primary data 
sources, categorized in Tables 2 through IV, and the Appendix. For primary data sources (i.e., those not specific to any journal article), additional references were sought to establish whether they satisfied each scale, topic, and attribute in the tables.

\section{Results}

The following sections describe the data sources that were found to be relevant to various aspects of diversion, nonmedical use, and the adverse outcomes associated with pharmaceutical opioids, as shown in Tables II through IV. Data sources' capacity for geographical and longitudinal trend analysis will not be discussed in detail, but results are available in the Appendix. In all tables, row headings indicate prominent topics, while column headings indicate the highest scale at which the data source is relevant. Sources are arranged by bullets within a table cell to differentiate large scale primary sources from independent studies. Bullets containing the name of a primary source are followed by informational resources and example analyses. Bullets without a source name contain the independent studies that have been conducted for a given topic and scale level. Sources that can be accessed publicly are indicated with bold type font, and sources that do not strictly limit responses to pharmaceutical opioids, but imply them (e.g., listing "pain killers," "pain relievers," or "narcotics other than heroin") are indicated with an asterisk. Key highlights among the predominant data sources for nonmedical use, diversion, and adverse outcomes are provided in the sections below.

\section{Nonmedical use table}

Table II categorizes data sources by central topics in the prevalence, frequency, and characteristics of those who use pharmaceutical opioids nonmedically in the United States. Because of the illegal nature of nonmedical opioid use, its prevalence is measured most often through self-report surveys, especially among non-patient populations [24-31]. Among patient populations, prevalence of nonmedical use is measured with either survey $[16,24,32]$ or toxicology methods, such as urine screening $[24,33,34]$. In addition to prevalence, some surveys ask about the frequency of nonmedical use during a recent period of time [26,35-40], or about the age of initiation [5,41,42], or duration [43] of nonmedical use. Other studies measure prevalence among more specific populations, such as parturients [44], club goers [36], student pharmacists [14], healthcare workers [12,13], and probationers [17].

A great amount of attention is paid to determining the characteristics of nonmedical opioid users $[8,45,46]$. Not surprisingly, a large number of data sources capture demographic information, which allows nonmedical use of pharmaceutical opioids to be studied in terms of age, gender, and racial/ ethnic differences. Additional characteristics include income [42,47], employment status $[27,28,42,47,48]$, housing status [42,48], educational performance [46] and attainment [16], physical health $[16,30,31,47]$, mental health $[16,17,30,31,32,34,46]$, and legal or behavioral problems $[34,42,47]$. Social characteristics include marital status $[16,27,28,49]$, family structure $[27,28,49]$, social support [17], urbanicity [50] and community size [9], as well as college-level characteristics [51]. Several studies have also measured motivations for nonmedical use, such as pain relief, experimentation, or "getting high" $[9,14,24,37,38,52]$, as well as attitudes about the perceived risk of using pharmaceutical opioids nonmedically [9]. Two additional topics of importance include common routes of administration [9,13,37,38,48,53-57], and polydrug use behaviors [5,13,15,29,35,38,42,43,58,59], which make the potential harm of nonmedical use especially high [43].

\section{Diversion table}

Table III provides categorization of sources based on their relevance to the diversion of pharmaceutical opioids. Diversion is defined as the transfer of pharmaceutical opioids from their lawful purpose to 


\begin{tabular}{|c|c|c|c|c|}
\hline \multirow{2}{*}{$\begin{array}{l}\text { Topics: nonmedical } \\
\text { use }\end{array}$} & \multicolumn{4}{|c|}{ Scale $^{\circ}$} \\
\hline & National & State & Multi-center & Single-Center \\
\hline $\begin{array}{l}\text { Prevalence of misuse/ } \\
\text { abuse among patients }\end{array}$ & $\begin{array}{l}\square \text { Toxicology [33] } \\
\square[88]\end{array}$ & & $\begin{array}{l}\square \text { RADARS }^{\circledast}[25,75] \\
\square[16,32,34]\end{array}$ & \\
\hline $\begin{array}{l}\text { Prevalence of } \\
\text { nonmedical use } \\
\text { among non-patients }\end{array}$ & $\begin{array}{l}\square \text { DAWN }[6,82,89] \\
\square \text { MTF* }^{*}[9,39] \\
\square \text { NAVIPPRO }[57,86,90] \\
\square \text { NESARC* }[91-93] \\
\square \text { NLAES* }[92] \\
\square \text { NSDUH }^{*}[7,41,46,94] \\
\square[51]\end{array}$ & $\begin{array}{l}\left.\square \text { CDAS* }^{*} 30,31,95\right] \\
\square[12]\end{array}$ & $\begin{array}{l}\square \text { RADARS }^{\circledast}[25,75] \\
\square\left[13,36^{*}, 37,96\right]\end{array}$ & $\begin{array}{l}\square[14,24,26,29,35, \\
38,42]\end{array}$ \\
\hline $\begin{array}{l}\text { Frequency of } \\
\text { nonmedical use }\end{array}$ & $\begin{array}{l}\square \text { MTF* }^{*}[39] \\
\square \text { NSDUH }^{*}[40,94]\end{array}$ & & $\square[36]^{*}$ & $\square[26,35,38]$ \\
\hline $\begin{array}{l}\text { Initiation of } \\
\text { nonmedical use }\end{array}$ & $\begin{array}{l}\square \text { NAVIPPRO }[86,90] \\
\square \text { NSDUH }[2,41,94]\end{array}$ & & $\square$ RADARS $^{\circledast}[75]$ & $\square[42]$ \\
\hline $\begin{array}{l}\text { Individual } \\
\text { characteristics of } \\
\text { those exhibiting } \\
\text { nonmedical use }\end{array}$ & $\begin{array}{l}\square \text { DAWN }[6,82] \\
\square \text { MTF* }[9] \\
\square \text { NAVIPPRO }[57,86,90] \\
\square \text { NESARC }[92,93] \\
\square \text { NLAES* }[92] \\
\square \text { NSDUH }^{*}[7,40,41,46, \\
\quad 47,68-70,94] \\
\square \text { NVSS }[83,97] \\
\square \text { TEDS }[98,99] \\
\square \text { Toxicology [33] }\end{array}$ & 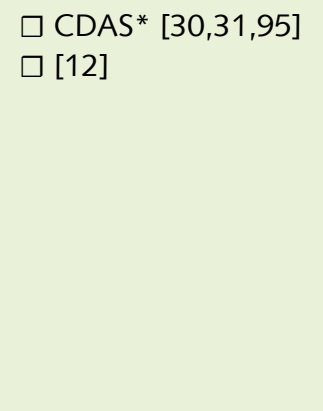 & $\begin{array}{l}\square \text { RADARS }^{\circledast}[50,75] \\
\square\left[13,16,32,34,36^{*},\right. \\
37,48]\end{array}$ & $\begin{array}{c}\square \text { Treatment Centers } \\
{[45,100,101]} \\
\square[15,17,24,35,38, \\
42,52,58]\end{array}$ \\
\hline $\begin{array}{l}\text { Social characteristics } \\
\text { of those exhibiting } \\
\text { nonmedical use }\end{array}$ & 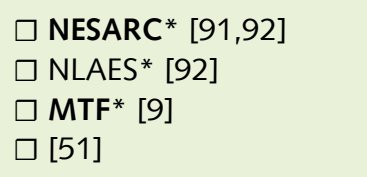 & $\square$ CDAS* $^{*}[30,31,95]$ & $\begin{array}{l}\square \text { RADARS }^{\circledast}[50] \\
\square\left[36^{*}, 48\right]\end{array}$ & $\square[17]$ \\
\hline $\begin{array}{l}\text { Motivations/ } \\
\text { attitudes toward } \\
\text { nonmedical use }\end{array}$ & $\square$ MTF* [9] $^{2}$ & & $\begin{array}{l}\square \text { RADARS }^{\circledast}[102] \\
\square[37]\end{array}$ & $\square[14,24,38,52,66]$ \\
\hline $\begin{array}{l}\text { Routes of } \\
\text { administration }\end{array}$ & $\begin{array}{l}\square \text { MTF* }[39] \\
\square \text { NAVIPPRO }[57,86,90] \\
\square \text { NPDS }[10,72,84] \\
\square \text { NSDUH* }[53,54,94]\end{array}$ & & $\begin{array}{l}\square \text { RADARS }^{\circledast}[55] \\
\square[13,37,48]\end{array}$ & $\square[38,42]$ \\
\hline $\begin{array}{l}\text { Prevalence of } \\
\text { polydrug use }\end{array}$ & $\begin{array}{l}\square \text { DAWN }[6,82] \\
\square \text { NAVIPPRO }[86,90]\end{array}$ & & $\square[13]$ & $\begin{array}{l}\square[15,29,35,38,42, \\
58,59]\end{array}$ \\
\hline
\end{tabular}

Table II. Categorization of data sources regarding the nonmedical use of pharmaceutical opioids CDA = Center for Drug and Alcohol Studies; DAWN = Drug Abuse Warning Network; MTF = Monitoring the Future; NAVIPPRO = National Addictions Vigilance Intervention and Prevention Program; NESARC $=$ National Epidemiologic Survey on Alcohol and Related Conditions, NLAES = National Longitudinal Alcohol Epidemiology Survey; NPDS = National Poison Data System; NSDUH = National Survey on Drug Use and Health;

NVSS $=$ National Vital Statistics System; RADARS $^{\oplus}=$ Researched Abuse, Diversion and Addiction-Related Surveillance; TEDS = Treatment Episode Data Set

* Source measurement does not strictly limit responses to pharmaceutical opioids, but instead lists "pain killers," "pain medicine," "pain relievers," or "narcotics other than heroin"

- Scale categorization indicates the highest geographical scale at which the source is relevant. Many sources also have more detailed information at smaller scales than are listed here Bold type font indicates a data source that is publicly available 


\begin{tabular}{|c|c|c|c|c|}
\hline \multirow{2}{*}{ Topics: diversion } & \multicolumn{4}{|c|}{ SCALE $^{\circ}$} \\
\hline & National & State & Multi-center & Single-center \\
\hline $\begin{array}{l}\text { Controlled substances } \\
\text { transactions/tracking }\end{array}$ & $\square \operatorname{ARCOS}[62,63,103]$ & & & \\
\hline $\begin{array}{l}\text { Prescription drug } \\
\text { diversion by } \\
\text { healthcare workers }\end{array}$ & & & $\square$ RADARS $^{\circledR}[65]$ & $\begin{array}{l}\square \text { Police Records [64] } \\
\square[18,66]\end{array}$ \\
\hline $\begin{array}{l}\text { Sources of prescription } \\
\text { drugs }\end{array}$ & $\begin{array}{l}\square \text { MTF* }^{*}[39,67] \\
\square \text { NAVIPPRO }[57,86] \\
\square \text { NSDUH* } \\
{[68,70,94,104]}\end{array}$ & $\square$ CDAS* $^{*}[30,31,95]$ & $\begin{array}{c}\square \text { RADARS }^{\circledR} \\
{[50,65,75]} \\
\square[37,105]\end{array}$ & $\square[14,29]$ \\
\hline Availability of opioids & $\square M^{2} F^{*}[9]$ & $\square$ CDAS* $^{*}[30,31,95]$ & $\square[71,105,106]$ & \\
\hline $\begin{array}{l}\text { Prescription drug } \\
\text { post-marketing } \\
\text { surveillance }\end{array}$ & $\begin{array}{l}\square \text { DAWN }[6,82] \\
\square \text { NAVIPPRO } \\
{[57,86,90]} \\
\square \text { NPDS }[10,72,84]\end{array}$ & & $\begin{array}{l}\square \text { RADARS }^{\circledR}[73-75] \\
\square[71]\end{array}$ & \\
\hline
\end{tabular}

Table III. Categorization of data sources regarding diversion of pharmaceutical opioids

ARCOS = Automation of Reports and Consolidated Order System; CDAS = Center for Drug and Alcohol

Studies; DAWN = Drug Abuse Warning Network; MTF = Monitoring the Future; NAVIPPRO = National

Addictions Vigilance Intervention and Prevention Program; NPDS = National Poison Data System;

$\mathrm{NSDUH}=$ National Survey on Drug Use and Health; RADARS $^{\circledR}=$ Researched Abuse, Diversion and Addiction-

Related Surveillance

* Source measurement does not strictly limit responses to pharmaceutical opioids, but instead lists "pain

killers," "pain medicine," "pain relievers," or "narcotics other than heroin"

- Scale categorization indicates the highest geographical scale at which the source is relevant. Many sources also have more detailed information at smaller scales than are listed here

Bold type font indicates a data source that is publicly available

illicit use [60]. The manufacturing and delivery of pharmaceutical opioids to retail locations is monitored by the Drug Enforcement Agency (DEA) through the Automation of Reports and Consolidated Orders System (ARCOS) [61]. Various routes of diversion can disrupt the supply chain of pharmaceutical opioids between their production and lawful distribution to patients. Large scale thefts are recorded by the DEA [62,63], and diversion by healthcare workers is captured in police records [64], through the RADARS ${ }^{\circ}$ key informant network [65], and in independent studies [18,66].

Other routes of diversion can be measured through self-reports of individuals who have acquired pharmaceutical opioids through illicit means. Monitoring the Future [39,67] the National Survey of Drug Use and Health (NSDUH) [68-70], the National Addictions Vigilance Intervention and Prevention Program (NAVIPPRO) [57], and the Delaware School Survey [30,31] all ask respondents questions regarding the source of nonmedically used pharmaceutical opioids. Diversion can also be measured indirectly by asking respondents whether they believe pharmaceutical opioids could be easily acquired for nonmedical use $[9,30,31]$, and through post-marketing surveillance techniques such as monitoring online forums [71] and measuring the prevalence of accidental poisonings [5,10,72-74] and substance abuse treatment $[43,57,75]$.

\section{Adverse outcomes table}

Table IV categorizes data on a variety of adverse outcomes associated with pharmaceutical opioids. Topics included in this table are not meant to imply causal relationships, but indicate a variety of nega- 
tive outcomes that have been found to be associated with nonmedical opioid use, such as fatal and nonfatal opioid poisonings, substance use disorders, addiction relapse, violence and suicide. A common measurement for many of these adverse outcomes is the International Classification of Diseases (ICD-10) [76], which contains medical codes for opioid dependence, opioid abuse, and unintentional poisonings due to methadone, heroin, or "other opioids." These codes are the basis for much of the data collected through hospital medical records [77-79], insurance claims [79], and death certificates which indicate instances where unintentional opioid poisoning was recorded as the primary cause of death [80,81]. Data regarding emergency department visits for nonfatal opioid poisonings can be accessed through the Drug Abuse Warning Network (DAWN) [82], and data regarding fatal opioid poisonings are available through the CDC's National Vital Statistics System (NVSS) [83].

Other common measurements of adverse outcomes include those gathered by poison call centers, treatment centers, and surveys. The National Poison Data System (NPDS) [84] is a prominent national

\begin{tabular}{|c|c|c|c|c|}
\hline \multirow{2}{*}{$\begin{array}{l}\text { Topics: adverse } \\
\text { outcomes }\end{array}$} & \multicolumn{4}{|c|}{ SCALE ${ }^{\circ}$} \\
\hline & National & State & Multi-center & Single-center \\
\hline $\begin{array}{l}\text { Prevalence of fatal } \\
\text { opioid poisoning }\end{array}$ & $\begin{array}{l}\square \text { NPDS }[10,72,84] \\
\square \text { NVSS }[83,97,107]\end{array}$ & $\begin{array}{l}\square \text { Medical Examiners } \\
{[80,81]}\end{array}$ & & $\begin{array}{l}\square \text { Medical Records } \\
{[108]}\end{array}$ \\
\hline $\begin{array}{l}\text { Prevalence of opioid } \\
\text { poisoning (nonfatal } \\
\text { or fatality unspecified) }\end{array}$ & $\begin{array}{l}\square \text { DAWN }[6,82,109] \\
\square \text { NIS }[78,110] \\
\square \text { NPDS } \\
{[10,72,84,111]}\end{array}$ & $\begin{array}{l}\square \text { CDAS* }^{*}[30,31,95] \\
\square \text { Insurance Claims } \\
\text { Data [79] }\end{array}$ & $\square$ ACMT [77] & $\begin{array}{l}\square \text { Medical Records } \\
\quad[108] \\
\square[17]\end{array}$ \\
\hline $\begin{array}{l}\text { Prevalence of } \\
\text { substance use } \\
\text { disorders }\end{array}$ & $\begin{array}{l}\square \text { DAWN }[6,82] \\
\square \text { NAVIPPRO } \\
{[57,86,90]} \\
\square \text { NESARC* } \\
{[91,92,93]} \\
\square \text { NLAES* }[92]^{*} \text { NSDUH* }^{*} \\
{[40,47,68,94]} \\
\square \text { VA Medical Records } \\
{[112]}\end{array}$ & $\begin{array}{l}\square \text { Treatment Centers } \\
{[85]} \\
\square \text { CDAS* [30,[31,95] } \\
\square \text { Insurance Claims } \\
\text { Data [79] }\end{array}$ & & $\square[26,35,38]$ \\
\hline Addiction relapse & $\square$ NAVIPPRO $[57,86]$ & $\square[12]$ & & \\
\hline $\begin{array}{l}\text { Suicide, violence, } \\
\text { violent suicide }\end{array}$ & $\begin{array}{l}\square \text { DAWN }[6,82] \\
\square \text { NVDRS [113] } \\
\square \text { NVSS }[83,112]\end{array}$ & & & \\
\hline Domestic impact & $\square$ NPDS [84,114] & & & \\
\hline
\end{tabular}

Table IV. Categorization of data sources regarding adverse outcomes associated with pharmaceutical opioids

ACMT = American College of Medical Toxicology; CDAS = Center for Drug and Alcohol Studies;

DAWN = Drug Abuse Warning Network; NAVIPPRO = National Addictions Vigilance Intervention and

Prevention Program; NESARC = National Epidemiologic Survey on Alcohol and Related Conditions;

NIS = Nationwide Inpatient Sample; NLAES = National Longitudinal Alcohol Epidemiology Survey;

NPDS = National Poison Data System; NSDUH = National Survey on Drug Use and Health; NVDRS = National

Violent Death Reporting System; NVSS = National Vital Statistics System; VA = Veterans Affairs)

* Source measurement does not strictly limit responses to pharmaceutical opioids, but instead lists "pain

killers," "pain medicine," "pain relievers," or "narcotics other than heroin"

- Scale categorization indicates the highest geographical scale at which the source is relevant. Many sources also have more detailed information at smaller scales than are listed here

Bold type font indicates a data source that is publicly available 
data source for nonfatal opioid poisonings, collecting data from 57 poison call centers throughout the United States. Information regarding the prevalence of opioid use disorders $[43,57,85]$ as well as addiction relapse [12,57] are captured by substance abuse treatment centers, such as those monitored by the National Addictions Vigilance Intervention and Prevention Program (NAVIPPRO ${ }^{\circ}$ [86]. Several questions on the NSDUH can also be used to determine whether participants have opioid dependence $[40,47,68]$, and independent studies have used surveys to measure outcomes such as dependence and withdrawal symptoms [26,30,35,38], and witnessing or experiencing an overdose [17].

\section{Discussion}

The categorization of data sources in Tables II through IV can serve as a guide for those who seek data sources regarding the diversion, nonmedical use, and adverse outcomes associated with pharmaceutical opioids in the United States. Global trends in data source coverage are illustrated as a bi-partite network in Figure 1. Topics from Tables II through IV are listed on the left, and primary data sources are listed on the right. Connections indicate coverage of topics by data sources, illustrating (1) variety among sources in the number of topics they cover, as well as (2) variety among topics in the number of

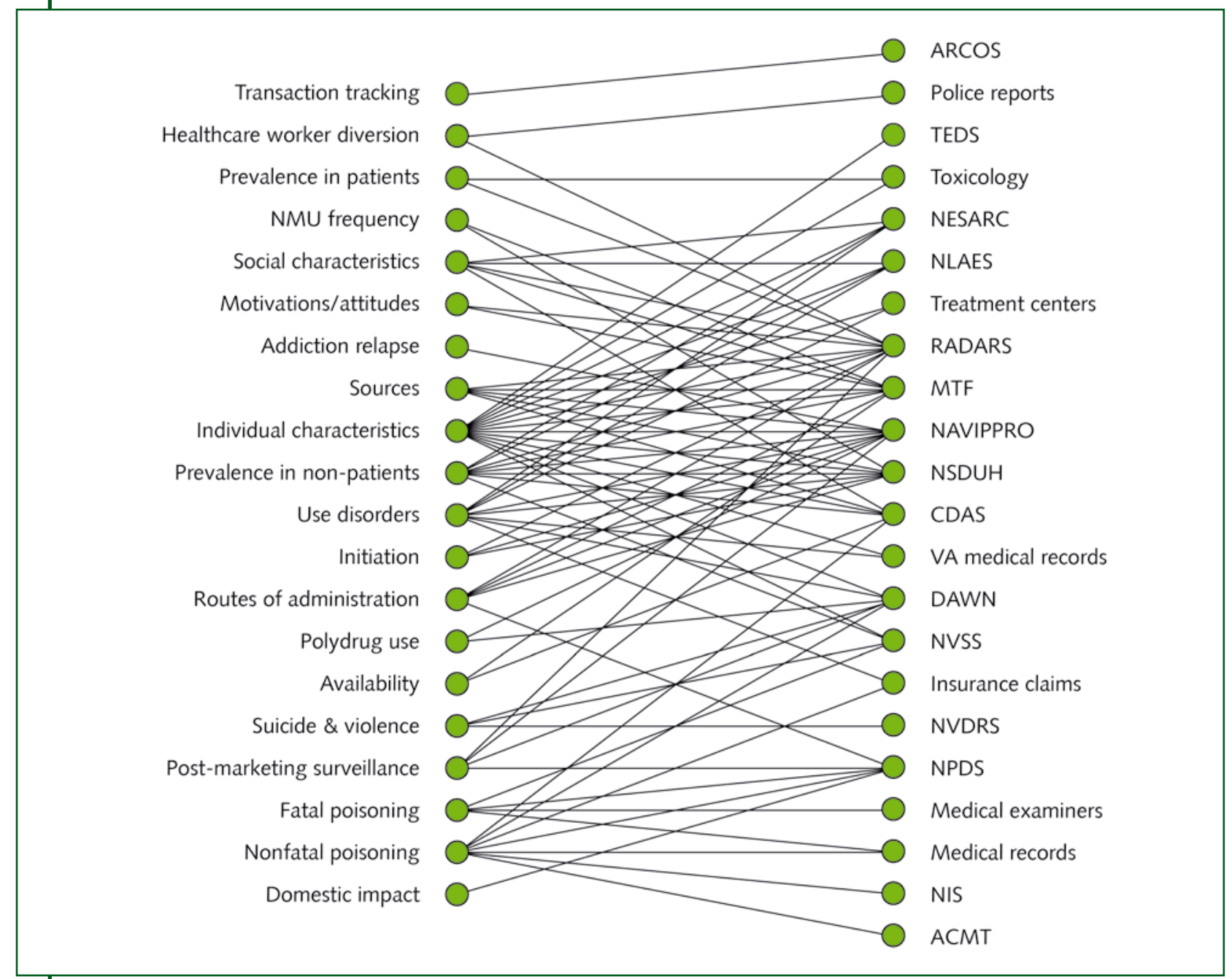

Figure 1. Bi-partite network depicting connections between large scale sources and topics 
sources that cover them. The topical coverage of each source is shown by the number of connections that stem from it. Large scale sources such as NAVIPPRO, RADARS, MTF, and DAWN collect data that is relevant for many topics within the pharmaceutical opioid public health problem. Other sources in this review, such as the National Inpatient Survey (NIS), Automation of Reports and Consolidated Orders System (ARCOS), the American College of Medical Toxicology (ACMT), and Veterans Affairs (VA) Medical records, are relevant to only one topic.

In a similar manner, the source coverage of each topic is shown by the number of connections that lead to it. Some topics are covered by more data sources than others. More than half of the primary sources contain data regarding individual characteristics of those exhibiting behaviors of nonmedical use of pharmaceutical opioids. Many sources also cover prevalence, opioid use disorders, illicit sources, social characteristics, and routes of administration. By contrast, addiction relapse, domestic impact, and transaction tracking were each covered by only one primary data source. The scarcity of sources covering some topical areas may be due to sufficiency of a single source, such as the Drug Enforcement Agency's ARCOS tracking system, or mortality data from National Vital Statistics System (NVSS). However, scarcity of sources covering other topical areas may indicate a need for additional data collection, such as addiction relapse or polydrug use, both of which have been found to be pertinent to this public health problem [12,15].

\section{Limitations}

Much effort was made to conduct an exhaustive search for data sources and a comprehensive examination of their relevance to prominent topics in the field. However, the current work is subject to several limitations. First, the original list of keywords stemmed from an existing library that was not created for the purpose of this project. Second, although $\mathrm{PubMed}^{\circledR}$ is updated daily and has been identified as an optimal tool for electronic searches [87], this search engine focuses primarily on medicine and biomedical sciences, and may have excluded some relevant sources. Data sources may also have been inadvertently excluded if their direct relevance to nonmedical opioid use was not discussed in peerreviewed academic literature. Third, the identification of prominent topics was conducted subjectively by members of a larger research project which uses System Dynamics to investigate the nonmedical use of pharmaceutical opioids in the United States. Filtration and categorization of sources may also have been subject to human error.

Additional limitations to this work stem from its boundaries of inclusion. A specific focus on nonmedical use of pharmaceutical opioids led to the exclusion of data sources regarding medical use of pharmaceutical opioids for pain treatment as well as for treatment of individuals exhibiting opioid or opiate abuse. These boundaries made the project much more feasible, but preclude its usefulness for these related topics. Searches in PubMed were also limited to the time period between January 1995 and April 2012.

\section{Conclusions}

This work offers a systematic categorization of data sources pertaining to the nonmedical use of pharmaceutical opioids in the United States. Data sources are categorized according to their relevance to a number of prominent topics in the areas of diversion, nonmedical use, and adverse outcomes associated with pharmaceutical opioids. Sources are also organized according to their capacity for geographical and longitudinal trend analysis. This categorization, provided in Tables II through IV, and the Appendix, can be used as a guide for researchers, policy makers, and others who seek data regarding various aspects of this public health problem. In addition, these tables show the distribution of data coverage across topics, indicating which topics are covered by more and fewer sources. This work serves to increase awareness of data sources that exist, suggests topics that may require additional data collection, and is hoped to facilitate ongoing research, analysis, and evaluation of this public health problem. 
Directions for further research

Researchers, policymakers, and other professionals in the health care field are encouraged to refer to the tables in this article when identifying data sources for ongoing research, analysis, and evaluation of this public health problem. In addition, data collection efforts are needed to address several topics that appear to have few data sources covering them, including nonmedical use frequency, addiction relapse, polydrug use, availability of pharmaceutical opioids for nonmedical use, domestic impact, and transaction tracking. With relatively few data sources identified, measurement of these topics would likely be beneficial for understanding and ameliorating the diversion, nonmedical use, and adverse outcomes associated with pharmaceutical opioids in the United States.

The review in brief

Clinical This work offers a systematic categorization of data sources regarding the diversion, nonmedical use, and question adverse outcomes associated with pharmaceutical opioids in the United States.

Type of Systematic

review

Search of the Searches were conducted using PubMed ${ }^{\circledR}$, with three sets of keywords:

literature - Opioid/Opioids, Misuse/Noncompliance/Non-Compliance/Diversion

- Opioid/Opioids, Deaths/Drug-Related Harm/Fatal Outcome/Mortality/Overdose/Poisoning

- Opioid/Opioids, Abuse/Aberrant Drug-Related Behaviors/Addiction/Abuse Liability/Problem Drug Use/ Substance Use Disorders/ Substance-Related Disorders/Substance Related Disorders/ Nonmedical Use/ Non-Medical Use/ Non-Medical Use

All sources were categorized according to their relevance to each of 20 topics and 2 design features.

Conclusions Tables cataloging data sources can be used to identify data relevant to specific topics in diversion, nonmedical use, and adverse outcomes, and for their capacity for geographical and longitudinal trend analysis. Global trends in coverage suggest that some topics have been measured plentifully, while others only minimally. The importance of some topics may warrant further data collection, including nonmedical use frequency, addiction relapse, polydrug use, availability of pharmaceutical opioids for nonmedical use, domestic impact, and transaction tracking.

Limitations Searches were conducted solely in PubMed $^{\circledR}$, and were restricted to peer-reviewed academic journals. Keywords were identified through an existing collection of resources from a separate research project which uses computer simulation to investigate the public health problem of nonmedical opioid use. Identification of prominent topics was conducted subjectively by members of this simulation research project. Filtration and categorization of sources may also have been subject to human error.

\section{References}

1. Compton WM, Volkow ND. Abuse of prescription drugs and the risk of addiction. Drug Alcohol Depend 2006; 83: S4-S7; http://dx.doi.org/10.1016/j.drugalcdep.2005.10.020

2. Substance Abuse and Mental Health Services Administration. Results from the 2011 national survey on drug use and health: national findings. Rockville: Department of Health and Human Services, 2012

3. Colliver JD, Kroutil LA, Dai L, et al. Misuse of prescription drugs: data from the 2002, 2003 and 2004 national surveys on drug use and health. Rockville, Md.: Dept. of Health and Human Services, Substance Abuse and Mental Health Services Administration, Office of Applied Studies; 2006. Available at: http://www.samhsa.gov/data/prescription/toc.htm (last accessed March 2013) 
4. Warner M, Chen LH, Makuc DM. NCHS Data Brief. Hyattsville Md Natl Cent Heal Stat Us. 2009: 1999-2006

5. Substance Abuse and Mental Health Services Administration. Results from the 2010 national survey on drug use and health: national findings. Rockville: Department of Health and Human Services, 2011

6. Substance Abuse and Mental Health Services Administration. Drug Abuse Warning Network, 2009: National Estimates of Drug-Related Emergency Department Visits. 2011. Available at: http://www.samhsa.gov/data/2k11/DAWN/2k9DAWNED/PDF/DAWN2k9ED.pdf (last accessed March 2013)

7. Tetrault JM, Desai RA, Becker WC, et al. Gender and non-medical use of prescription opioids: results from a national US survey. Addiction 2007; 103: 258-68; http://dx.doi.org/10.1111/j.13600443.2007.02056.x

8. Back SE, Lawson KM, Singleton LM, et al. Characteristics and correlates of men and women with prescription opioid dependence. Addict Behav 2011; 36: 829-34; http://dx.doi.org/10.1016/j.addbeh.2011.03.013

9. Johnston LD, O’Malley PM, Bachman JG, et al. Monitoring the future: National results on adolescent drug use: 2012 Overview : Key Findings on Adolescent Drug Use. Overv Key Find 2013. Available at: http://radar.boisestate.edu/radar/pdfs/mtf-overview2010.pdf (last accessed March 2013)

10. Bronstein AC, Spyker DA, Cantilena LR Jr, et al. 2011 Annual report of the American Association of Poison Control Centers' National Poison Data System (NPDS): 29th Annual Report. Clin Toxicol Phila Pa 2012; 50: 911-1164; http://dx.doi.org/10.3109/15563650.2012.746424

11. Paulozzi LJ. Opioid analgesic involvement in drug abuse deaths in American metropolitan areas. J Inf 2006; 96: 1755-7

12. Paris RT, Canavan DI. Physician substance abuse impairment: anesthesiologists vs. other specialties. J Addict Dis 1999; 18: 1-7; http://dx.doi.org/10.1300/J069v18n01_01

13. Skipper GE, Campbell MD, DuPont RL. Anesthesiologists with substance use disorders: a 5-year outcome study from 16 state physician health programs. Anesth Analg 2009; 109: 891-6; http:// dx.doi.org/10.1213/ane.0b013e3181adc39d

14. Lord S, Downs G, Furtaw P, et al. Nonmedical use of prescription opioids and stimulants among student pharmacists. J Am Pharm Assoc 2009; 49: 519; http://dx.doi.org/10.1331/JAPhA.2009.08027

15. Daniulaityte R, Falck R, Wang J, et al. Illicit use of pharmaceutical opioids among young polydrug users in Ohio. Addict Behav 2009; 34: 649-53; http://dx.doi.org/10.1016/j.addbeh.2009.03.037

16. Roeloffs CA, Wells KB, Ziedonis D, et al. Problem substance use among depressed patients in managed primary care. Psychosomatics 2002; 43: 405-12; http://dx.doi.org/10.1176/appi.psy.43.5.405

17. Havens JR, Oser CB, Knudsen $\mathrm{HK}$, et al. Individual and network factors associated with non-fatal overdose among rural Appalachian drug users. Drug Alcohol Depend. 2011; 115: 107-12; http:// dx.doi.org/10.1016/j.drugalcdep.2010.11.003

18. Parran TV Jr, Grey SF. The role of disabled physicians in the diversion of controlled drugs. J Addict Dis 2000; 19: 35-41; http://dx.doi.org/10.1300/J069v19n03_03

19. Katz N. Abuse-deterrent opioid formulations: are they a pipe dream? Curr Rheumatol Rep 2008; 10): 11-18; http://dx.doi.org/10.1007/s11926-008-0003-z

20. Center for the Application of Prevention Technologies. Sources of Consequence Data Related to Non-medical Use of Prescription Drugs (National and Local).

21. Forrester JW. Industrial dynamics. Cambridge, Mass.: M.I.T. Press, 1961

22. Sterman J. Business dynamics: systems thinking and modeling for a complex world. Boston: Irwin/McGraw-Hill, 2000 
23. Wakeland W, Schmidt T, Gilson AM, et al. System Dynamics Modeling as a Potentially Useful Tool in Analyzing Mitigation Strategies to Reduce Overdose Deaths Associated with Pharmaceutical Opioid Treatment of Chronic Pain. Pme Pain Med Suppl 2 2011; 12: S49-S58

24. Boyd CJ, McCabe SE, Cranford JA, et al. Adolescents' motivations to abuse prescription medications. Pediatrics 2006; 118: 2472-80; http://dx.doi.org/10.1542/peds.2006-1644

25. Cicero TJ, Inciardi JA, Surratt H. Trends in the use and abuse of branded and generic extended release oxycodone and fentanyl products in the United States. Drug Alcohol Depend 2007; 91: $115-$ 20; http://dx.doi.org/10.1016/j.drugalcdep.2007.05.008

26. McCabe SE, Boyd CJ, Young A. Medical and nonmedical use of prescription drugs among secondary school students. J Adolesc Health 2007; 40: 76-83; http://dx.doi.org/10.1016/j.jadohealth.2006.07.016

27. Chen CM, Yi H, Falk DE, et al. Alcohol use and alcohol use disorders in the United States: Main findings from the 2001-2002 National Epidemiologic Study on Alcohol and Related Conditions (NESARC), 2006. Available at: http://pubs.niaaa.nih.gov/publications/nesarc_drm/nesarcdrm. htm (last accessed February 2013)

28. Chen CM, Yi H, Dawson DA, et al. Alcohol and alcohol use disorders in the United States, a 3-year follow-up: Main findings from the 2004-2005 Wave 2 National Epidemiologic Survey on Alcohol and Related Conditions (NESARC), 2010. Available at: http://pubs.niaaa.nih.gov/publications/ NESARC_DRM2/NESARC2DRM.htm (last accessed February 2013)

29. McCabe SE, Boyd CJ. Sources of prescription drugs for illicit use. Addict Behav 2005; 30: 1342-50; http://dx.doi.org/10.1016/j.addbeh.2005.01.012

30. Center for Drug and Alcohol Studies. Delaware Secondary School Student Assent and Survey instructions, 2011. Available at: http://www.udel.edu/delawaredata/Files/DSS/225793-13\%20secondary\%20back\%20from\%20s.pdf (last accessed March 2013)

31. Center for Drug and Alcohol Studies. The Delaware School Survey: Alcohol, Tobacco, and Other Drug Abuse Among Delaware Students, 2011. Available at: http: //www.udel.edu/delawaredata/ Pages/level03/delschsurv.htm (last accessed March 2013)

32. Becker WC, Fiellin DA, Gallagher RM, et al. The association between chronic pain and prescription drug abuse in Veterans. Pain Med 2009; 10: 531-36; http://dx.doi.org/10.1111/j.15264637.2009.00584.x

33. Couto JE, Romney MC, Leider HL, et al. High rates of inappropriate drug use in the chronic pain population. Popul Heal Manag 2009; 12: 185-190; http://dx.doi.org/10.1089/pop.2009.0015

34. Jamison RN, Butler SF, Budman SH, et al. Gender differences in risk factors for aberrant prescription opioid use. J Pain Off J Am Pain Soc 2010; 11: 312-20; http://dx.doi.org/10.1016/j. jpain.2009.07.016

35. McCabe SE. Screening for drug abuse among medical and nonmedical users of prescription drugs in a probability sample of college students. Arch Pediatr Adolesc Med 2008; 162: 225-31; http:// dx.doi.org/10.1001/archpediatrics.2007.41

36. Kelly BC, Parsons JT. Prescription drug misuse among club drug-using young adults. Am J Drug Alcohol Abuse 2007; 33: 875-84; http://dx.doi.org/10.1080/00952990701667347

37. McCabe SE, West BT, Teter CJ, et al. Adolescent nonmedical users of prescription opioids: brief screening and substance use disorders. Addict Behav 2012; 37: 651-6; http://dx.doi.org/10.1016/j. addbeh.2012.01.021

38. McCabe SE, Boyd CJ, Teter CJ. Subtypes of nonmedical prescription drug misuse. Drug Alcohol Depend 2009; 102: 63-70; http://dx.doi.org/10.1016/j.drugalcdep.2009.01.007

39. Johnston LD, Bachman JG, O’Malley PM, et al. Monitoring the Future: A Continuing Study of American Youtn (12th-Grade Survey), 2008 Available at: http://www.icpsr.umich.edu/cgi-bin/file ?comp=none\&study=25382\&ds=2\&file_id=992579 (last accessed March 2013) 
40. Martins SS, Ghandour LA, Chilcoat HD. Profile of dependence symptoms among extramedical opioid analgesic users. Addict Behav 2007; 32: 2003-19; http://dx.doi.org/10.1016/j.addbeh.2007.01.006

41. Sung HE, Richter L, Vaughan R, et al. Nonmedical use of prescription opioids among teenagers in the United States: Trends and correlates. J Adolesc Health 2005; 37: 44-51; http://dx.doi. org/10.1016/j.jadohealth.2005.02.013

42. Young AM, Havens JR. Transition from first illicit drug use to first injection drug use among rural Appalachian drug users: a cross-sectional comparison and retrospective survival analysis. Addict Abingdon Engl 2012; 107: 587-96; http://dx.doi.org/10.1111/j.1360-0443.2011.03635.x

43. Green TC, Black R, Serrano JMG, et al. Typologies of Prescription Opioid Use in a Large Sample of Adults Assessed for Substance Abuse Treatment. Plos One 2011; 6: 1-10; http://dx.doi.org/10.1371/ journal.pone.0027244

44. Kain ZN, Mayes LC, Ferris CA, et al. Cocaine-abusing parturients undergoing cesarean section. A cohort study. Anesthesiology 1996; 85: 1028-35; http://dx.doi.org/10.1097/00000542-19961100000010

45. Becker WC, Meghani SH, Barth KS, et al. Characteristics and Outcomes of Patients Discharged from the Opioid Renewal Clinic at the Philadelphia VA Medical Center. Am J Addict 2009; 18: 135-9; http://dx.doi.org/10.1080/10550490902772496

46. Schepis TS, Krishnan-Sarin S. Characterizing adolescent prescription misusers: a populationbased study. J Am Acad Child Adolesc Psychiatry 2008; 47: 745-54; http://dx.doi.org/10.1097/ CHI.0b013e318172ef0ld

47. Becker WC, Sullivan LE, Tetrault JM, et al. Non-medical use, abuse and dependence on prescription opioids among U.S. adults: psychiatric, medical and substance use correlates. Drug Alcohol Depend 2008; 94: 38-47; http://dx.doi.org/10.1016/j.drugalcdep.2007.09.018

48. Grau LE, Dasgupta N, Grau LE, et al. Illicit Use of Opioids: Is OxyContin a "Gateway Drug”? Am J Addict 2007; 16: 166-173; http://dx.doi.org/10.1080/10550490701375293

49. Stinson FS, Yi H, Grant BF, et al. Drinking in the United States: Main findings from the $1992 \mathrm{Na}-$ tional Longitudinal Alcohol Epidemiologic Survey (NLAES), 1998. Available at: http://www.seas. harvard.edu/climate/eli/Courses/EPS281r/Sources/OH-reactivity/more/weinstock-niki-1972.pdf (last accessed February 2013)

50. Rosenblum A, Parrino M, Schnoll SH, et al. Prescription opioid abuse among enrollees into methadone maintenance treatment. Drug Alcohol Depend 2007; 90: 64-71; http://dx.doi.org/10.1016/j. drugalcdep.2007.02.012

51. McCabe SE, West BT, Wechsler H. Trends and college-level characteristics associated with the non-medical use of prescription drugs among US college students from 1993 to 2001. Addiction 2007; 102: 455-65; http://dx.doi.org/10.1111/j.1360-0443.2006.01733.x

52. Hartwell KJ, Back SE, McRae-Clark AL, et al. Motives for using: A Comparison of prescription opioid, marijuana and cocaine dependent individuals. Addict Behav 2011. Available at: http:// www.sciencedirect.com/science/article/pii/S0306460311003765 (last accessed January 2013)

53. Substance Abuse and Mental Health Services Administration. SAMHSA, 2011

54. Substance Abuse and Mental Health Services Administration. NSDUH Report: Injection Drug Use Update: 2002 and 2003. Available at: http://www.samhsa.gov/data/2k5/IVdrug/IVdrug.pdf (last accessed March 2013)

55. Buchholtz C, Thomasset C, Bailey JE, et al. Administration routes involved in non-medical use of long-acting opioids in the RADARS ${ }^{\circledast}$ System College Survey and Poison Center Programs. Clinical Toxicology 2005; 43: 631-777; http://dx.doi.org/10.1080/15563650500269633

56. Hughes AA, Dart RC, Bailey JE. Lick or stick: The common routes of the misuse and abuse of fentanyl. Clinical Toxicology 2010; 48: 604-67; http://dx.doi.org/10.3109/15563650.2010.493290 
57. Butler SF, Budman SH, Licari A, et al. National addictions vigilance intervention and prevention program (NAVIPPRO ${ }^{\mathrm{TM}}$ ): a real-time, product-specific, public health surveillance system for monitoring prescription drug abuse. Pharmacoepidemiol Drug Saf 2008; 17: 1142-54; http:// dx.doi.org/10.1002/pds.1659

58. Peters RJ, Williams M, Ross MW, Atkinson J, Yacoubian GS. Codeine cough syrup use among African-American crack cocaine users. J Psychoactive Drugs. 2007; 39(1): 97-102; http://dx.doi.or g/10.1080/02791072.2007.10399868

59. McCabe SE, West BT, Teter CJ, et al. Co-ingestion of prescription opioids and other drugs among high school seniors: Results from a national study. Drug Alcohol Depend 2012; 126: 65-70; http:// dx.doi.org/10.1016/j.drugalcdep.2012.04.017

60. Rigg KK, March SJ, Inciardi JA. Prescription Drug Abuse \& Diversion: Role of the Pain Clinic. J Drug Issues 2010; 40: 681-702

61. Office of Diversion Control. ARCOS Registrant Handbook, 1997. Available at: http://www.deadiversion.usdoj.gov/arcos/handbook/full.pdf (last accessed March 2013)

62. Joranson DE, Ryan KM, Gilson AM, et al. Trends in medical use and abuse of opioid analgesics. Jama J Am Med Assoc 2000; 283: 1710-14; http://dx.doi.org/10.1001/jama.283.13.1710

63. Joranson DE, Gilson AM. Drug Crime Is a Source of Abused Pain Medications in the United States. J Pain Symptom Manage 2005; 30: 299301; http://dx.doi.org/10.1016/j.jpainsymman.2005.09.001

64. Inciardi JA, Surratt HL, Kurtz SP, et al. The diversion of prescription drugs by health care workers in Cincinnati, Ohio. Subst Use Misuse 2006; 41:255-64; http://dx.doi.org/10.1080/10826080500391829

65. Inciardi JA, Surratt HL, Cicero TJ, et al. The "black box" of prescription drug diversion. J Addict Dis 2009; 28: 332-47; http://dx.doi.org/10.1080/10550880903182986

66. Chan L, Winegard B. Attributes and behaviors associated with opioid seeking in the emergency department. J Opioid Manag 2007; 3): 244-8

67. Inciardi JA, Surratt HL, Cicero TJ, et al. Prescription drugs purchased through the internet: Who are the end users? Drug Alcohol Depend 2010; 110: 21-9; http://dx.doi.org/10.1016/j.drugalcdep.2010.01.015

68. Back SE, Payne RL, Simpson AN, et al. Gender and prescription opioids: Findings from the National Survey on Drug Use and Health. Addict Behav 2010; 35: 1001-7; http://dx.doi.org/10.1016/j. addbeh.2010.06.018

69. Martins SS, Storr CL, Zhu H, et al. Correlates of extramedical use of OxyContin ${ }^{\circledR}$ versus other analgesic opioids among the US general population. Drug Alcohol Depend 2009; 99: 58-67; http://dx.doi.org/10.1016/j.drugalcdep.2008.06.013

70. Schepis TS, Krishnan-Sarin S. Sources of prescriptions for misuse by adolescents: differences in sex, ethnicity, and severity of misuse in a population-based study. J Am Acad Child Adolesc Psychiatry 2009; 48: 828-36; http://dx.doi.org/10.1097/CHI.0b013e3181a8130d

71. Butler SF, Venuti SW, Benoit C, et al. Internet surveillance: content analysis and monitoring of product-specific internet prescription opioid abuse-related postings. Clin J Pain 2007; 23: 619-28; http://dx.doi.org/10.1097/AJP.0b013e318125c5cf

72. Bailey JE, Barton PL, Lezotte D, et al. The effect of FDA approval of a generic competitor to OxyContin (oxycodone $\mathrm{HCl}$ controlled-release) tablets on the abuse of oxycodone. Drug Alcohol Depend 2006; 84: 182-7; http://dx.doi.org/10.1016/j.drugalcdep.2006.01.011

73. Cicero TJ, Dart RC, Inciardi JA, et al. The Development of a Comprehensive Risk-Management Program for Prescription Opioid Analgesics: Researched Abuse, Diversion and AddictionRelated Surveillance (RADARS). Pain Med 2007; 8: 157-70; http://dx.doi.org/10.1111/j.15264637.2006.00259.x

74. Dasgupta N, Bailey EJ, Cicero T, et al. Post-marketing surveillance of methadone and buprenorphine in the United States. Pain Med Malden Mass 2010; 11: 1078-91; http://dx.doi.org/10.1111/ j.1526-4637.2010.00877.x 
75. Cicero TJ, Ellis MS, Paradis A, et al. Role of key informants and direct patient interviews in epidemiological studies of substance abuse. Pharmacoepidemiol Drug Saf 2011; 20: 308-12; http:// dx.doi.org/10.1002/pds.2075

76. World Health Organization. International statistical classification of diseases and related health problems. Geneva: World Health Organization, 1992

77. Brent J, Wax PM, Schwartz T, et al. The Toxicology Investigators Consortium Case Registry - The 2010 Experience. J Med Toxicol 2011: 1-11

78. Cox S, Kuo C, Jamieson DJ, et al. Poisoning hospitalisations among reproductive-aged women in the USA, 1998-2006. Inj Prev 2011; 17: 332-7; http://dx.doi.org/10.1136/ip.2010.029793

79. White AG, Birnbaum HG, Schiller M, et al. Analytic models to identify patients at risk for prescription opioid abuse. Am J Manag Care 2009; 15): 897-906

80. Fernandez W, Hackman H, Mckeown L, et al. Trends in opioid-related fatal overdoses in Massachusetts, 1990-2003. J Subst Abuse Treat 2006; 31: 151-6; http://dx.doi.org/10.1016/j.jsat.2006.04.008

81. Landen MG, Castle S, Nolte KB, et al. Methodological issues in the surveillance of poisoning, illicit drug overdose, and heroin overdose deaths in New Mexico. Am J Epidemiol 2003; 157: 273-8; http://dx.doi.org/10.1093/aje/kwf196

82. Substance Abuse and Mental Health Services Administration. Drug Abuse Warning Network (DAWN), 2012. Available at: http://www.samhsa.gov/data/dawn.aspx (last accessed March 2013)

83. Centers for Disease Control and Prevention. NVSS - Mortality Data. Available at: http://www.cdc. gov/nchs/deaths.htm (last accessed March 2013)

84. American Association of Poison Control Centers. National Poison Data System. Available at: http://www.aapcc.org/data-system (last accessed March 2013)

85. Gold MS, Melker RJ, Dennis DM, et al. Fentanyl abuse and dependence: further evidence for second hand exposure hypothesis. J Addict Dis 2006; 25: 15-21; http://dx.doi.org/10.1300/J069v25n01_04

86. Inflexxion, Inc., NAVIPPRO. Improving The Risk-Benefit Balance Of Prescription Medications. 2013. Available at: http://www.navippro.com/default.aspx (last accessed March 2013)

87. Falagas ME, Pitsouni EI, Malietzis GA, et al. Comparison of PubMed, Scopus, Web of Science, and Google Scholar: strengths and weaknesses. Faseb J 2008; 22: 338-42; http://dx.doi.org/10.1096/ fj.07-9492LSF

88. Heimer R, Dasgupta N, Irwin KS, et al. Chronic pain, Addiction severity, and misuse of opioids in Cumberland County, Maine. Addict Behav 2011. Available at: http://www.sciencedirect.com/ science/article/pii/S0306460311003790 (last accessed January 2013)

89. Manchikanti L, Fellows B, Ailinani H. Therapeutic use, abuse, and nonmedical use of opioids: a ten-year perspective. Pain Physician 2010; 13: 401-35.

90. Green TC, Black R, Serrano JMG, et al. Typologies of prescription opioid use in a large sample of adults assessed for substance abuse treatment. Plos One 2011; 6: e27244; http://dx.doi.org/10.1371/ journal.pone.0027244

91. National Institute on Alcohol Abuse and Alcoholism. Alcohol and alcohol use disorders in the United States, a 3-year follow-up: Main findings from the 2004-2005 Wave 2 National Epidemiologic Survey on Alcohol and Related Conditions (NESARC). U.S. Alcohol Epidemiologic Data Reference. NIH Publication No. 10-7677, 2010 Available at: http://pubs.niaaa.nih.gov/publications/NESARC_DRM2/NESARC2DRM.htm (last accessed March 2013)

92. Martins SS, Keyes KM, Storr CL, et al. Birth-cohort trends in lifetime and past-year prescription opioid-use disorder resulting from nonmedical use: results from two national surveys. J Stud Alcohol Drugs 2010; 71: 480-7

93. McCabe SE, West BT, Morales M, et al. Does early onset of non-medical use of prescription drugs predict subsequent prescription drug abuse and dependence? Results from a national study. Addiction 2007; 102: 1920-30; http://dx.doi.org/10.1111/j.1360-0443.2007.02015.x 
94. U.S. Department of Health and Human Services. Substance Abuse and Mental Health Data Archive (SAMHDA). Browse Download Data, 2010

95. Center for Drug and Alcohol Studies. Delaware School Survey: Alcohol, Tobacco \& Other Drug Abuse Among Delaware Students 2010. Available at: http://www.udel.edu/delawaredata/ Files/2010StateReport.pdf (last accessed March 8)

96. Havens JR, Oser CB, Leukefeld CG, et al. Differences in prevalence of prescription opiate misuse among rural and urban probationers. Am J Drug Alcohol Abuse 2007; 33: 309-17; http://dx.doi. org/10.1080/00952990601175078

97. Centers for Disease Control and Prevention (U.S.), National Center for Injury Prevention and Control (U.S.). Unintentional drug poisoning in the United States, 2010. Available at: http://www. cdc.gov/HomeandRecreationalSafety/Poisoning/brief_full_page.htm (last accessed March 2013)

98. Substance Abuse and Mental Health Services Administration. Treatment Episode Data Set (TEDS). Available at: http://wwwdasis.samhsa.gov/dasis2/teds.htm (last accessed March 2013)

99. Substance Abuse and Mental Health Services Administration. Treatment Episode Data Set (TEDS) 1997-2007: National Admissions to Substance Abuse Treatment Services, 2009. Available at: http:// www.samhsa.gov/data/DASIS/TEDS2k7AWeb/TEDS2k7AWeb.pdf (last accessed March 2013

100. Meade CS, McDonald LJ, Weiss RD. HIV risk behavior in opioid dependent adults seeking detoxification treatment: an exploratory comparison of heroin and oxycodone users. Am J Addict 2009; 18: 289-93; http://dx.doi.org/10.1080/10550490902925821

101. Potter JS, Hennessy G, Borrow JA, et al. Substance use histories in patients seeking treatment for controlled-release oxycodone dependence. Drug Alcohol Depend 2004; 76: 213-5; http://dx.doi. org/10.1016/j.drugalcdep.2004.05.001

102. Montoya AM, Zolot, LM, Bailey, JE, et al. Motives for non-medical prescription opioid use among RADARS(R) System College Survey respondents-Indication of a substance abuse disorder? The College on Problems of Drug Dependence 2009 Annual Meeting

103. Office of Diversion Control. ARCOS REGISTRANT HANDBOOK, 1997

104. Martins SS, Storr CL, Zhu H, et al. Correlates of extramedical use of OxyContin versus other analgesic opioids among the US general population. Drug Alcohol Depend 2009; 99: 58-67; http:// dx.doi.org/10.1016/j.drugalcdep.2008.06.013

105. Cicero TJ, Shores CN, Paradis AG, et al. Source of drugs for prescription opioid analgesic abusers: a role for the Internet? Pain Med 2008; 9: 718-23; http://dx.doi.org/10.1111/j.1526-4637.2007.00323.x

106. Forman R, Woody G, McLellan T, et al. The availability of web sites offering to sell opioid medications without prescriptions. Am J Psychiatry 2006; 163: 1233-8; http://dx.doi.org/10.1176/appi. ajp.163.7.1233

107. Bohnert ASB, Ilgen MA, Galea S, et al. Accidental poisoning mortality among patients in the Department of Veterans Affairs Health System. Med Care 2011; 49: 393-6

108. Paredes VL, Rea TD, Eisenberg MS, et al. Out-of-hospital Care of Critical Drug Overdoses Involving Cardiac Arrest. Acad Emerg Med 2004; 11: 71-4; http://dx.doi.org/10.1197/j.aem.2003.08.014

109. Paulozzi LJ. Opioid Analgesic Involvement in Drug Abuse Deaths in American Metropolitan Areas. Am J Public Health 2006; 96: 1755-7; http://dx.doi.org/10.2105/AJPH.2005.071647

110. Healthcare Cost and Utilization Project. Overview of the Nationwide Inpatient Sample (NIS). 2013. Available at: http://www.hcup-us.ahrq.gov/nisoverview.jsp (last accessed March 2013)

111. Forrester MB. Temporal and Geographic Patterns in Opioid Abuse in Texas. J Addict Dis 2012; 31: 93-9; http://dx.doi.org/10.1080/10550887.2012.665694

112. Ilgen MA, Conner KR, Valenstein M, et al. Violent and nonviolent suicide in veterans with substance-use disorders. J Stud Alcohol Drugs 2010; 71: 473-9

113. Centers for Disease Control and Prevention (U.S.). National Violent Death Reporting System (NVDRS), 2011. Available at: http://www.cdc.gov/injury/wisqars/nvdrs.html (last accessed March 2013) 
114. Bailey JE, Campagna E, Dart RC, RADARS System Poison Center Investigators. The underrecognized toll of prescription opioid abuse on young children. Ann Emerg Med 2009; 53: 419-24; http:// dx.doi.org/10.1016/j.annemergmed.2008.07.015

115. Montoya AM, Heltshe SL, Dart RC. Spatial Analysis of RADARS System Data to Identify Geographic Hot Spots of Prescription Opioid Abuse. The College on Problems of Drug Dependence Conference. San Juan, 2008

116. Substance Abuse and Mental Health Services Administration. Accessing National and State Data from the National Survey on Drug Use and Health. 2012. Available at: http://www.samhsa.gov/ data/2k12/NSDUH116/NSDUHShortReport116AccessingData2012.pdf (last accessed March 2013)

117. Curtis LH, Stoddard J, Radeva JI, et al. Geographic variation in the prescription of schedule II opioid analgesics among outpatients in the United States. Health Serv Res 2006; 41: 837-55

118. Gilson AM, Ryan KM, Joranson DE, et al. A reassessment of trends in the medical use and abuse of opioid analgesics and implications for diversion control: 1997-2002. J Pain Symptom Manage 2004; 28: 176-88; http://dx.doi.org/10.1016/j.jpainsymman.2004.01.003

119. Onpoint Health Data. Maine Health Data Processing Center 2011 Annual Report. 2011. Available at: http://www.mhdpc.org/extras/mhdpc_annual_report_2011.pdf (last accessed March 2013)

120. Cicero TJ, Inciardi JA, Munoz A. Trends in abuse of Oxycontin and other opioid analgesics in the United States: 2002-2004. J Pain 2005; 6: 662-72

121. Havens JR, Oser CB, Leukefeld CG. Increasing prevalence of prescription opiate misuse over time among rural probationers. J Opioid Manag 2007; 3): 107-11; http://dx.doi.org/10.1016/j. jpain.2005.05.004 


\section{Appendix}

Categorization of data sources by geographical and longitudinal design attributes

\begin{tabular}{|c|c|c|c|c|}
\hline \multirow{2}{*}{$\begin{array}{l}\text { Topics: data sources } \\
\text { by geographical and } \\
\text { longitudinal design } \\
\text { attributes }\end{array}$} & \multicolumn{4}{|c|}{ SCALE $^{\circ}$} \\
\hline & National & State & Multi-center & Single-center \\
\hline $\begin{array}{l}\text { Geographical trends in } \\
\text { opioid abuse }\end{array}$ & $\begin{array}{l}\square \text { ARCOS [62] } \\
\square \text { DAWN }[6,82] \\
\square \text { MTF* [9] } \\
\square \text { NAVIPPRO } \\
{[57,86,90]} \\
\square \text { NIS }[78,110] \\
\square \text { NPDS } \\
\quad[10,84,111,115] \\
\square \text { NSDUH* [116] } \\
\square \text { NVSS }[83,97] \\
\square \text { TEDS }[98,99] \\
\square \text { VA Medical Records } \\
\quad[112]\end{array}$ & $\begin{array}{l}\square \text { CDAS* }^{*}[30,31,95] \\
\square \text { Insurance Claims } \\
\text { Data [117] }\end{array}$ & $\square[96]$ & \\
\hline $\begin{array}{l}\text { Longitudinal }{ }^{\ddagger} \text { trends in } \\
\text { opioid abuse }\end{array}$ & $\begin{array}{l}\square \text { ARCOS }[62] \\
\square \text { DAWN }[6,82,89] \\
\square \text { MTF* }[9] \\
\square \text { NAVIPPRO }[57,86] \\
\square \text { NESARC }[91,92] \\
\square \text { NIS }[78,110] \\
\square \text { NLAES }[92] \\
\square \text { NSDUH* }[3,94] \\
\square \text { NVSS }[83,118] \\
\square \text { TEDS }[98,99] \\
\square \text { VA Medical Records } \\
\quad[112] \\
\square[51]\end{array}$ & $\begin{array}{l}\square \text { CDAS* }[30,31,95] \\
\square \text { Insurance Claims } \\
{[79,119]} \\
\square \text { Medical Examiners } \\
{[80]} \\
\square[12]\end{array}$ & $\begin{array}{l}\square \text { RADARS }^{\circledast}[120] \\
\square[13]\end{array}$ & $\square$ [121] \\
\hline
\end{tabular}

ARCOS = Automation of Reports and Consolidated Order System; CDAS = Center for Drug and Alcohol Studies; DAWN = Drug Abuse Warning Network; MTF = Monitoring the Future; NAVIPPRO = National Addictions Vigilance Intervention and Prevention Program; NESARC = National Epidemiologic Survey on Alcohol and Related Conditions; NIS = Nationwide Inpatient Sample; NLAES = National Longitudinal Alcohol Epidemiology Survey; NPDS = National Poison Data System; NSDUH = National Survey on Drug Use and Health; NVSS = National Vital Statistics System; RADARS ${ }^{\oplus}=$ Researched Abuse, Diversion and AddictionRelated Surveillance; TEDS = Treatment Episode Data Set; VA = Veterans Affairs

* Source measurement does not strictly limit responses to pharmaceutical opioids, but instead lists "pain killers," "pain medicine," "pain relievers," or "narcotics other than heroin"

- Scale categorization indicates the highest geographical scale at which the source is relevant. Many sources also have more detailed information at smaller scales than are listed here Bold type font indicates a data source that is publicly available

₹ Longitudinal data sources include cohort or panel studies as well as 'repeated cross sectional' studies 